\title{
Introducing a New Scheme for Rural Teachers to Enhance Computer Literacy
}

\author{
Dipali Railkar \\ Professor, MCA Department \\ Pimpri Chinchwad College of \\ Engineering, Pune
}

\author{
Poonam Katyare \\ Professor, MCA Department \\ Pimpri Chinchwad College of \\ Engineering, Pune
}

\author{
Anuradha Thakare \\ Professor, Dept of Computer \\ Science \\ Pimpri Chinchwad College of \\ Engineering, Pune
}

\begin{abstract}
Information and communication technology is the major tool to improve the quality of education. Indian Government invested huge amount for ICT to improve the education sector. Also, various ICT trainings are given to the school teachers through the government scheme. Though Pune is one of the top educational city, there is a lack of ICT tools in the rural area schools. This article is an extension to our earlier work based on requirement analysis of the computer literacy level of the rural and urban schools. The new scheme to improve the computer literacy level of rural teachers based on analysis of the rural teachers is proposed. The objective of defining this scheme is to enhance the capability of rural teachers to accept the new technology. This scheme mainly focuses on improving usage of computer, teaching skills and culture of rural education. This scheme will bridge the gap between rural and urban school teachers.
\end{abstract}

\section{Keywords}

Information and Communication Technology (ICT),

Computer Literacy, rural teachers.

\section{INTRODUCTION}

In today's world every sector makes use of information and computer technology (ICT) tool. ICT plays a vital role in people's lives and it is expected that in the next few years, it will become a part of their life. ICT means a huge range of hardware tools and enormous software devices such as computer, android devices, digital cameras, large database. It also includes the communication tools through which people can share information through the email, chatting, video conferencing, etc. The impact of ICT in educational sector will help to improve significantly in teaching and learning process. ICT will be a major motivational factor in students' learning. $[9,10]$

Today's world is digital and everyone is using the digital media like android mobile, computers, laptops, note one, tabs. These tools provide a service to the users wherever they require. Every individual tries to use such tools for the simple life.

These digital tools, especially computers have changed the human life by providing enormous facilities to the people. Computers changed industrial development, medical, education sectors, banking domains, etc., hence process became very easy. Hence computer literacy has become an essential part of the life.
Knowing how to use computer knowledge always helps to get work done in a more organized and appropriate manner, especially in your profession where you have to use a computer continuously. Computer programs such tally, word, power point, spreadsheet programs that help you to represent your views, but you should have hands on these programs so that you will be able to use various features, such as calculations, audio, and video, image editing etc.

People with adequate ICT literacy ability should possess both the familiar and the capability to use computers and the associated knowledge professionally. In education sector, government of Maharashtra is investing considerably in promoting ICT literacy among rural teachers by supplying computers and e-learning method. It is a significant commitment towards achieving a fully developed nation through the Vision 2020 plan.[7, 8] Therefore, it is crucial for the rural teachers to be equipped with necessary ICT skills in response to the workforce requirement.

The main objective of this study is to make an analysis of the computer literacy rate of rural and urban schools. And bring out positive development in learning Information technology to improve the quality of teaching by empowering rural teachers.

Depending on the analysis, identify the factors which are affecting on the computer literacy. Also to increase computer literacy levels of teachers, by making them aware about the role of ICT and its usage in the process of development.

The courses which are offered in the market are expensive and delivered in English, whereas $80 \%$ of the rural teachers are more convenient in their local language. Thus we had the immense need to start a center for rural teachers to give training on the basics and advanced computer skills using the local language. The education which we are going to provide for the rural teachers is based on their requirement and in the same way the scheme is designed.

To achieve this we have formed the scheme that will help the rural teachers improve their computer literacy level. This scheme will build the confidence among the rural teachers and will help to improve the educational level of rural area.

\section{RELATED WORK}

This paper builds on the earlier study and investigation of our project, which helped us to accomplish the objectives of our research project. 


\subsection{Evaluation of related work}

We have studied various research work based on the enhancement of the computer literacy in rural area. The research papers represent the analysis of the students affected with school dropout. [4]. As computer plays a major role now a days, what are the factors affecting on computer literacy in rural and urban area schools.[5] Government has provided various schemes to the rural area school for usage of the computer but the facilities are not used for the teachers and students. Teachers should create the interest in learning the computer and improve the computer skills.[6]. Following is the table of analysis that we have made based on the various research papers.

Table 1, Depict for evaluation of related work

\begin{tabular}{|c|c|c|c|c|}
\hline $\begin{array}{l}\text { Sr. } \\
\text { No. }\end{array}$ & Title & Author & Strength & Remarks \\
\hline 1. & $\begin{array}{l}\text { Mining The } \\
\text { Factors Affecting } \\
\text { The High School } \\
\text { Dropouts In Rural } \\
\text { Areas }\end{array}$ & $\begin{array}{l}\text { P. Sunil Kumar, } \\
\text { Ashok Kumar } \\
\text { Panda, D. Jena }\end{array}$ & $\begin{array}{l}\text { In this paper seven different parameters are } \\
\text { used to find the relationship between two } \\
\text { different factors affecting the school } \\
\text { dropout. } \\
\text { This paper is based on a survey work which } \\
\text { proposes to apply association rule mining } \\
\text { measures like support confidence and other } \\
\text { interesting measures on these major factors } \\
\text { of high school dropouts to understand the } \\
\text { problem in a better way and to have a } \\
\text { proper planning for retention of students. }\end{array}$ & $\begin{array}{l}\text { The paper does not suggest a method } \\
\text { to improve the educational standard. } \\
\text { Also paper does not express any } \\
\text { technique for improving the student } \\
\text { and teachers' performance in } \\
\text { education. }\end{array}$ \\
\hline 2. & $\begin{array}{l}\text { A Comparative } \\
\text { Study of Computer } \\
\text { Literacy in Urban } \\
\text { and Rural Primary } \\
\text { Schools in Rivers } \\
\text { State of Nigeria }\end{array}$ & $\begin{array}{l}\text { Achuonye } \\
\text { Keziah Akuoma, } \\
\text { Department of } \\
\text { Curriculum } \\
\text { Studies } \\
\text { University of } \\
\text { Education, } \\
\text { Port Harcourt, } \\
\text { Rivers State. }\end{array}$ & $\begin{array}{l}\text { The paper represents Challenges retarding } \\
\text { computer literacy in Nigerian Primary } \\
\text { schools, particularly in rural area. } \\
\text { Also paper suggests that there is need of } \\
\text { urgent interventions from the government } \\
\text { and public spirited organizations and } \\
\text { individuals. }\end{array}$ & $\begin{array}{l}\text { The paper presented various } \\
\text { recommendations like giving teachers } \\
\text { free access to the computer usage. } \\
\text { Providing well equipped computer } \\
\text { lab. } \\
\text { But paper has not expressed the } \\
\text { technique of how to enhance the } \\
\text { computer literacy skill. }\end{array}$ \\
\hline 3. & $\begin{array}{l}\text { Assessment Of } \\
\text { Computer Literacy } \\
\text { Of Secondary } \\
\text { School Teachers } \\
\text { In Ekiti State, } \\
\text { Nigeria }\end{array}$ & $\begin{array}{l}\text { James Ayodele } \\
\text { Oluwatayo, } \\
\text { University of } \\
\text { Ado-Ekiti, } \\
\text { Nigeria }\end{array}$ & $\begin{array}{l}\text { This study assessed computer literacy of } \\
\text { secondary school teachers in Ekiti State. } \\
\text { It was suggested that regular } \\
\text { workshops/seminars be organized for } \\
\text { teachers to acquire desirable skills in } \\
\text { computers for realization of the objectives } \\
\text { of computer education in Nigeria. }\end{array}$ & $\begin{array}{l}\text { This paper presents that Teachers } \\
\text { should create sound interest and self- } \\
\text { development in computer education. } \\
\text { But the paper has not given } \\
\text { methodology, a scheme or seminar } \\
\text { contents so as to improve the skills. } \\
\text { Also, they have not applied any } \\
\text { training to these rural schools. }\end{array}$ \\
\hline
\end{tabular}

We had made a survey with the population of Devale village which is situated at Taluka Maval in Pune district and we found that people in devale are back as compared to urban citizens in education and ICT usage. [2]

Problems associated with the use of ICT by teachers.

- $\quad$ Lack of enough training for teachers.

- Insufficient time for teachers to plan for effective use of ICT in their lessons.

- Shortage of computers.

- $\quad$ Lack of technical support.

\subsection{Proposed Approach}

The study was a descriptive survey that involved the collection of data through a questionnaire. Through this questionnaire analysis of the existing conditions in rural and urban primary schools regarding the computers and literacy level of the teachers is made. By using a sampling technique we have collected rural data from Maval Taluka and urban data from Pimpri Chinchwad area in Pune.

We have selected 25 rural and 25 urban schools. 10 teachers from each school filled the questionnaire and total 500 teacher's data is collected for the analysis. To understand the questionnaire, we personally communicated to the teachers so that we can get the true data from them. For the questionnaire distribution and data collection we have taken the students from our department on the hiring service basis. [3]

The questionnaire is based on the need, usage, importance and literacy level of the computer. 


\section{PURPOSE OF INTRODUCING NEW SCHEME}

Based on the questionnaire data we have made the analysis of the literacy level of the rural teachers. This analysis was based on what is the level of competency in using computers in day to day activity and in the educational sector by rural teachers. [3]

Following are the finding based on the questionnaire

1. That more urban school possesses computers, and students are allowed to use the computer on a regular basis as compared to rural.

2. There are usually computer experts are available in urban schools for computer teaching as well as the computer subject examination is conducted, but in a rural area no experts are available for the same.

3. Both rural and urban teachers think that with the help of computer literacy employment will rise.

4. That both rural and urban teacher's experiences high accessibility to computers, which are used mainly for educational purpose rather than office work or individual use.

5. That more teachers in urban areas are computer literate and use computer literacy skills for educational purpose.

6. Both rural and urban teachers think that there is an optimistic impact of computer literacy of the student so as to improve the study; they also think that they will become more confident in the academics.

\subsection{Design of Course Module}

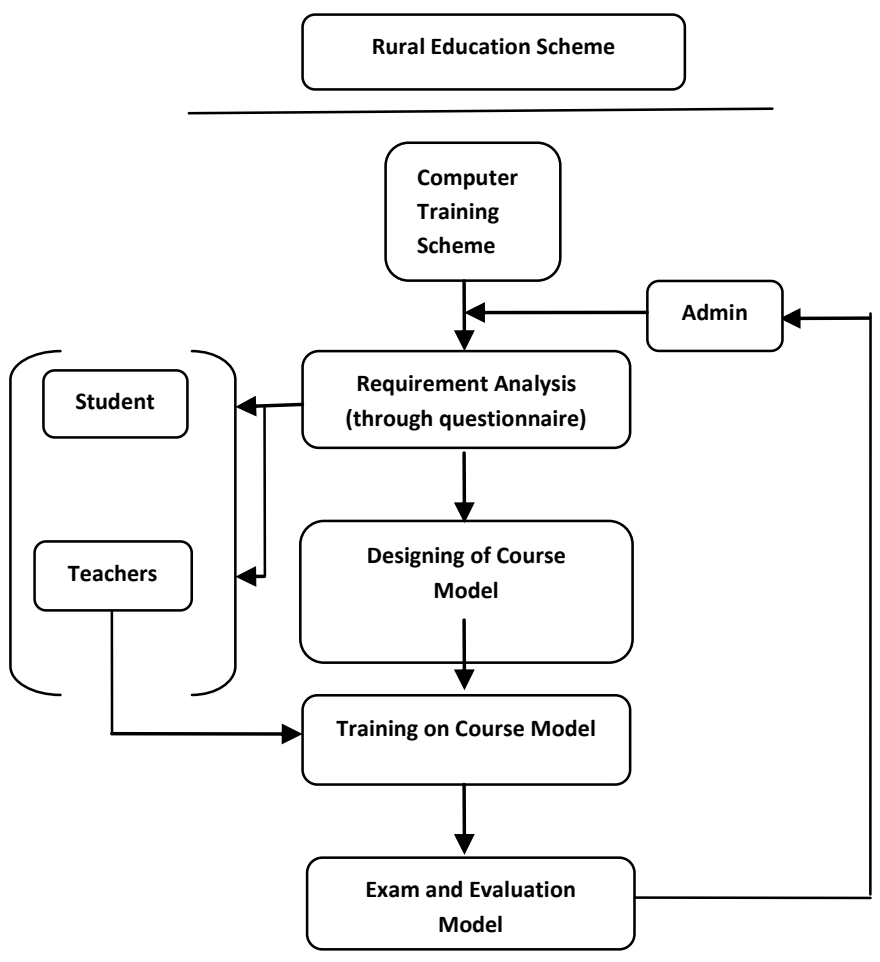

Fig 1: Architecture of Proposed work

\subsection{Brief Description of Scheme}

Following are the details of the scheme that will be implemented in the rural area so as to improve the level of computer literacy of rural teachers.

As the teachers are having the heavy academic load and they are not able to spend more time on learning the new technology. This scheme is designed based on the time availability and requirements of the rural teacher so that the desired outcome will be achieved by this scheme.

Day1: Computer Basics, Introduction to Hardware, Demonstration and Hands on Assembly of the Computer

Day 2: Basic of Computer networks, Web Browsers, Concept $\&$ Application of Internet, Email and its functions, Hands on Internet.

Day3: Word Processing, Text Creation and Manipulation, Formatting the Text, Table Manipulation, Preview \& Printing, Practical on word processing.

Day 4: Spreadsheets, formulas, functions used for data analysis, drawing different graphs, Practical on the spreadsheet.

Day 5: Creation of Presentation, Preparation of Slides, Selection of Slide Designs, Making your own Slides, Formatting of slides, and Presentation of the Slides, Demo and Practical, Introduction to other software or websites.

This scheme consists of different case studies which focus on the improvement of the computer literacy. These case studies are covering all the topics which are mentioned in the scheme. Through these case studies teachers will have hands on the computer and can resolve their queries at the time of training.

\subsection{Detail Syllabus}

1. Basic of Computer

Theory Session:

- Definition Of Computer

- Basic Application \& Features Of Computers

- Input \& Output Devices

- Concept Of Hardware And Software

- What is Data and Information?

- Concepts Of Computer Memory

- Important things while Purchasing A Computer

Practical Session:

- Assembly Of Computer

- Demo Of Turning A Computer On And Off

- Functioning Of Mouse

- Functioning Of Keyboard

\section{Computer Network And Internet}

Theory Session:

- Basic Of Computer Networks

- Definition Of Web Browser

- Functioning And Features Of Browser

- Concept Of Search Engine And Website.

- Comparison Of Search Engine

\section{Practical Session:}

- Accessing Internet Through Wired Connection, Dongle etc.

- Hands On Address Bar, Search Bar

- Finding information through various search engines. 
- Creating E-Mail Account

- Uploading /downloading the attachments through email.

- Chatting

- Video conferencing.

- Online purchasing, online payment etc.

3. Word processing

Both Theory \& Practical sessions are conducted together.

- An Introduction to Word Processing

- Opening Word Processing Package

- The Menu Bar

- Using the Icons below menu bar

- Open/ Close word files

- $\quad$ Save and Save AS

- $\quad$ Page Setup

- Printing of Documents

- Scrolling the Document

- Scrolling by line/paragraph

- $\quad$ Paragraph and Tab Setting

- Text Selection

- Cut, copy and paste

- Font and Size selection

- Bold ,Italic and Underline

- Alignment of Text

- Formatting the Text

- Table Manipulation

- $\quad$ Printing

4. Spread Sheet

Both Theory \& Practical sessions are conducted together.

- Applications and usage of Spread Sheet

- Introduction to menu bar

- What is a cell?

- Various operations on cells

- Enter text, numbers and dates

- Creation of tables

- Formatting of the tables.

- Cell Height and Widths

- Copying of cells

- $\quad$ Add/ delete rows \& columns

- Formatting.

- Using basic functions

- Sum, Average, Percentage function

- Other basic functions

- $\quad$ Sorting and filtering of the data

- Drawing the various charts

- Adding pictures, shapes, clip art.

\section{Presentation}

Both Theory \& Practical sessions are conducted together.

- Making Small Presentations

- Difference between PowerPoint and word

- Using Power Point

- Opening a Power Point Presentation

- Features of Wizard

- Creation of Presentation

- Formatting features like Fonts, Bullets etc.

- Preparation of Slides

- Selection of type of Slides
- Importing text from word documents

- Moving to next Slide

- The Slide manager

- Providing aesthetics

- $\quad$ Slide Designs

- Background and Text colors

- Making your own slide format

- Footnotes and slide numbering

- Slide Manipulation and Slide Show

\subsection{Outcome of Scheme}

After completion of the five days training, teachers will be able to

1. Apply the basic computer knowledge in day to day life.

2. Maintain all the academic records by using computer applications.

3. Make a use of Internet for giving better education to the rural students.

4. Use technology effectively for improving educational sector of rural area.

5. Deliver the educational contents by using computers.

\section{CONCLUSION}

In this paper, we have presented the analysis of our research work. From analysis of existing scheme, it is observed that the rural school teachers not getting sufficient facility and time to learn the new technology. Hence the proposed scheme is designed. Based on the analysis we are proposing the new scheme which is covering all the important concepts required for day to day activities by using a computer. From the analysis, we observed that the teachers of the rural schools are not getting sufficient facilities and time to learn the new technology. This scheme is designed in such a way that, with less time of spam they can become computer literate and can use their knowledge for improving the rural education. Also by completing the training through this scheme they will be able to get the different certification provided by the government schemes. The proposed research scheme aims towards improving the skills of rural school teaching as good as urban school teaching. It is expected that if computer literacy training is provided to teachers in rural area, then major changes in students and teachers will be observed. This scheme will bring consistent education structure in rural and urban school.

\section{ACKNOWLEDGMENTS}

We thank to Board of College and University Development which is an academic core unit of the Pune University for sanctioning research funding and encouraging to work in rural schools. We are also thankful to the teachers, students for helping us to complete the field work.

\section{REFERENCES}

[1] Computerized Manufacturing Automation: Employment, Education and the Workplace, Washington, US Congress of Technology Assessment, OTA CIT-235 April 1984, page 234 .

[2] Prof. Dipali Railkar \& Prof Poonam Katyare "ICT the Modernize Mediator for Better Science Education in Rural Area.'International Conference on ICPCCS12 on Dec10-12, 2012. 
[3] Prof. Dipali Railkar \& Prof Poonam Katyare" A Comparative Analysis of Computer Literacy in Rural And Urban Schools of Pune Region " International Journal of Innovative Research in Computer Science \& Technology, IJIRCST journal, Volume-2, Issue-6, November-2014, ISSN- 2347-5552.

[4] P.Sunil Kumar,Ashok Kumar Panda, D. Jena "Mining The Factors Affecting The High School Dropouts In Rural Areas" International Journal of Advanced Computer Engineering and Communication Technology (IJACECT), ISSN (Print): 2278-5140, Volume-2, Issue $3,2013$.

[5] Achuonye Keziah Akuoma,Department of Curriculum Studies "A Comparative Study of Computer Literacy in Urban and Rural Primary Schools in Rivers State of Nigeria" Journal of Sociological Research ISSN 19485468 2012, Vol. 3, No. 2.

[6] James Ayodele Oluwatayo, University of Ado-Ekiti, Nigeria "Assessment Of Computer Literacy Of
Secondary School Teachers In Ekiti State, Nigeria" Journal of International Education Research - Second Quarter 2012 Volume 8, Number 2.

[7] Norizan Mohamad,Azlin Dahlan,Mohd Talmizie Amron, Zairi Ismael Rizman "Automated ICT Literacy Skil Assessment Using RateSkill System" International Journal of Science and Research (IJSR), India Online ISSN: 2319-7064.

[8] Serhat Kurt "Examining teachers' use of computer-based technologies: A case study" Educ Inf Technol (2013) 18:557-570DOI 10.1007/s10639-012-9199-7.

[9] Maria Loftus \& Peter Tiernan \& Sebastian Cherian, Students' readiness to move from consumers to producers of digital video content: A cross-cultural analysis of Irish and Indian Students, Educ Inf Technol DOI 10.1007/s10639-013-9286-4.

[10] Niraj Kumar Roy "ICT-Enabled Rural Education in India" International Journal of Information and Education Technology, Vol. 2, No. 5, October 2012. 